\title{
Bacterial degradation of protein adsorbed to model submicron particles in seawater
}

\author{
T. Nagata ${ }^{1, *}$, D. L. Kirchman ${ }^{2}$ \\ ${ }^{1}$ Institute for Hydrospheric-Atmospheric Sciences, Nagoya University, Chikusa, Nagoya 464-01, Japan \\ ${ }^{2}$ College of Marine Studies, University of Delaware, Lewes, Delaware 19958, USA
}

\begin{abstract}
We tested the hypothesis that protein adsorbed to submicron particles in seawater is more slowly degraded than the same protein freely dissolved. Bacterial hydrolysis of methyl- ${ }^{3} \mathrm{H}$-bovine serum albumin ( ${ }^{3} \mathrm{H}-\mathrm{BSA}$ ) dissolved or adsorbed to particles (polystyrene latex beads, diameters 0.126 to $1.5 \mu \mathrm{m}$ ) was examined. Mixed bacterial assemblages cultured on BSA media, 2 bacterial isolates, and a natural marine bacterial assemblage hydrolyzed adsorbed ${ }^{3} \mathrm{H}-\mathrm{BSA}$ at much slower rates (1/10 to $<1 / 200$ ) than free ${ }^{3} \mathrm{H}$-BSA. We compared our hydrolysis rates with the predicted collision probabilities between bacteria and ${ }^{3} \mathrm{H}$-BSA freely dissolved or adsorbed to beads of different diameters. These comparisons suggest that the hydrolysis rate is influenced primarily by the transport rate of ${ }^{3} \mathrm{H}-\mathrm{BSA}$ to bacteria. Hydrolysis of adsorbed ${ }^{3} \mathrm{H}-\mathrm{BSA}$ differed greatly between 2 bacterial strains, which appears to be explained by differences in the affinity of bacterial proteases to ${ }^{3} \mathrm{H}$-BSA. Our results support the hypothesis that adsorption onto submicron particles greatly reduces degradation rate of proteins and suggest that the adsorption of dissolved organic matter (DOM) may be a mechanism that temporarily stores labile DOM in a slowly degrading, 'semi-labile' pool, which makes it available for export and further modification by geochemical processes
\end{abstract}

KEY WORDS: Bacterial degradation Dissolved organic matter · Adsorption · Colloids

\section{INTRODUCTION}

The recent discovery of many detrital colloids and submicron particles in a wide variety of oceanic environments (Koike et al. 1990, Wells \& Goldberg 1991, 1994) has renewed interests in the role of colloids in biogeochemical cycles of marine environments. These non-living organic colloids are much more abundant $\left(10^{6}\right.$ to $10^{10}$ particles $\mathrm{ml}^{-1}$, depending on size) than microorganisms including bacteria and viruses (Koike et al. 1990, Wells \& Goldberg 1991) and can represent a significant fraction (10 to $35 \%$ ) of the organic carbon pool in the oceans (Benner et al. 1992). The chemical nature, sources, sinks and turnover of colloids have yet to be clarified (Lee \& Wakeham 1992, Nagata \& Koike 1995).

One potentially important role of colloids and submicron particles in oceanic material cycling is that they

\footnotetext{
- Present address: Ocean Research Institute, The University of Tokyo, 1-15-1 Minami-dai, Tokyo 164, Japan.

E-mail:nagata@ori.u-tokyo.ac.jp
}

provide large solid surfaces to which dissolved organic matter (DOM) may adsorb. In fact, previous studies have shown that adsorption of polymeric DOM such as protein to surfaces in seawater can occur very rapidly (within minutes; Kirchman et al. 1989) and that the adsorption can have substantial effects on degradation rates of organic material (van Loosdrecht et al. 1990, Fletcher 1991). Keil \& Kirchman (1994) suggested that DOM adsorbed to colloids was less easily degraded than freely dissolved DOM. They found that dissolved protein aged in filtered seawater is abiotically modified to less biologically degradable protein in a short period ( $<10 \mathrm{~h})$, an observation that they could explain only by hypothesizing that dissolved proteins adsorb rapidly onto organic colloids and that these adsorbed proteins are less degradable than freely dissolved forms. This finding is potentially important for understanding formation of the refractory organic matter that dominates the DOM pool (Lee \& Wakeham 1992). However, how surfaces affect degradation of DOM by marine bacteria is poorly understood (reviewed by van 
Loosdrecht et al. 1990; also see Samuelson \& Kirchman 1990, Griffith \& Fletcher 1991, Taylor 1995).

The purpose of this study was to test the hypothesis that DOM adsorbed to submicron particles is more slowly degraded than the same DOM freely dissolved. We examined methyl- ${ }^{3} \mathrm{H}$-protein (bovine serum albumin, BSA) because of the importance of protein in carbon and nitrogen cycling (Keil \& Kirchman 1993) and because this labeled protein is a convenient model for high molecular weight DOM. Polystyrene latex beads of variable sizes $(0.1$ to $1.5 \mathrm{\mu m})$ were used as model submicron particles. Our data indicate that adsorption to submicron particles substantially reduces degradation rates of protein by free-living marine bacteria.

\section{MATERIALS AND METHODS}

Bacterial cuitures. Surface seawater was collected at Roosevelt Inlet near the mouth of the Delaware Bay (USA) with a polycarbonate bottle. The water was prefiltered through a $0.8 \mu \mathrm{m}$ pore-size Nuclepore filter, enriched with BSA (final conc. $1 \mathrm{mg} \mathrm{l}^{-1}$ ), and incubated at room temperature $\left(22^{\circ} \mathrm{C}\right)$ for $2 \mathrm{~d}$. A few drops of this 'preculture' were then added to the BSA medium and incubated in a shaking water bath at $35^{\circ} \mathrm{C}$ for $1 \mathrm{~d}$. The BSA medium was a BSA solution (final conc. $1 \mathrm{~g} \mathrm{l}^{-1}$ ) filter-sterilized (with $0.2 \mu \mathrm{m}$ Acrodisc, Gelman, Ann Arbor, MI, USA) and added to autoclaved artificial seawater (Samuelson \& Kirchman 1990) containing $\mathrm{Na}_{2} \mathrm{HPO}_{4}$ (final conc. $0.1 \mathrm{~g} \mathrm{I}^{-1}$ ).

The mixed assemblage of bacteria grown on the media was transferred to fresh media every day and used for the experiments. Bacterial strains were isolated and purified from the mixed assemblage by using BSA agar plates. The strains were maintained on the BSA liquid medium. In the present study, 2 bacterial isolates (PD2 and PD42) were used. For the experiments examining hydrolysis of ${ }^{3} \mathrm{H}$-protein, bacteria in early stationary phase were washed and resuspended in artificial seawater Bacteria were counted by acridine orange direct count method (Hobbie et al. 1977).

Adsorption of ${ }^{3} \mathrm{H}$-BSA to polystyrene beads. BSA was radiolabeled with ${ }^{3} \mathrm{H}$-borohydride according to Kirchman et al. (1989). The reductively ${ }^{3} \mathrm{H}$-methylated BSA was extracted by precipitation with trichloroacetic acid (TCA, final conc. $5 \%$ ). After the acid extraction (repeated 4 times) the BSA was resuspended in borate buffer $(0.2 \mathrm{M}$, pH 9.0). Low molecular weight (LMW) ${ }^{3} \mathrm{H}$ (TCA-soluble ${ }^{3} \mathrm{H}$ ) was $<0.1 \%$ of ${ }^{3} \mathrm{H}-\mathrm{BSA}$. Specific activity of the ${ }^{3} \mathrm{H}$-BSA was 0.07 to $0.09 \mu \mathrm{Ci}$ ( $\mu \mathrm{gg}$ $\mathrm{BSA}^{-1}$.

Fluorescent polystyrene beads (Bangs Laboratories, Carmel, IN, USA, type PS-FL) of different diameters $(0.126,0.50,0.840,1.500 \mu \mathrm{m})$ were used as model col- loids. Fluorescent beads were advantageous because we could easily enumerate beads by epifluorescence microscopy. Beads were collected on a $0.2 \mu \mathrm{m}$ poresize Nuclepore filter $(1.5,0.5$ and $0.8 \mu \mathrm{m}$ diameter beads) or a $0.02 \mu \mathrm{m}$ pore-size Anopore filter $10.1 \mu \mathrm{m}$ diameter beads), and counted by epifluorescence microscopy with blue excitation light. According to the manufacturer, no residues were deliberately added to the bead surfaces, and fluorescent dyes are trapped inside the beads

The beads were first washed with borate buffer (20 mM, pH 8.2) by centrifugation and resuspension. The suspension was sonicated to disperse the beads. ${ }^{3} \mathrm{H}-\mathrm{BSA}$ solution $(20 \mu \mathrm{l})$ was added to the beads suspension $(120 \mu \mathrm{l})$. After $1 \mathrm{~h}$ incubation, $750 \mu \mathrm{l}$ of borate buffer was added and the beads with adsorbed ${ }^{3} \mathrm{H}$ BSA were collected by centrifugation $(14000 \times g$ for $20 \mathrm{~min}$ for $0.126 \mu \mathrm{m}$ beads; $6000 \times g$ for $7 \mathrm{~min}$ for 0.5 , 0.840 and $1.500 \mu \mathrm{m}$ beads). The supernatant was discarded and the beads were resuspended in $1 \mathrm{ml}$ borate buffer by vortex mixing. This washing procedure was repeated 4 times to remove freely dissolved protein; after this separation, the remaining free protein was $0.3 \%$ of total ${ }^{3} \mathrm{H}-\mathrm{BSA}$. The amounts of adsorbed protein on the surface of beads were 152 to $290 \mathrm{ng} \mathrm{cm}^{-2}$, concentrations that could form a monolayer of protein molecules on the surface (see Taylor 1995). With epifluorescence microscopy, we did not observe large clumps ( $>10$ beads) of beads after vortex mixing; however, some particles (ca $30 \%$ ) formed clumps of 2 to 4 beads. We were unable to discriminate monodispersed beads and small clumps of $0.12 \mu \mathrm{m}$ beads because of the limits of epifluorescence microscopy. We did not sonicate the bead suspension after ${ }^{3} \mathrm{H}$-BSA adsorption in order to minimize desorption of ${ }^{3} \mathrm{H}$-BSA from the beads.

Hydrolysis of ${ }^{3} \mathrm{H}$-BSA freely dissolved and adsorbed to colloids. We added ${ }^{3} \mathrm{H}$-BSA solution or ${ }^{3} \mathrm{H}$ BSA adsorbed to beads to bacterial cell suspensions (70 to $1500 \mu \mathrm{l}$ ) and incubated the sample at room temperature $\left(22^{\circ} \mathrm{C}\right)$. Final concentrations of ${ }^{3} \mathrm{H}$-BSA were adjusted to $40-1300 \mathrm{ng} \mathrm{ml^{-1 }}$; bead concentrations varied depending on the experiment and the size of beads (see 'Results'). Bacterial cell densities were 1 to $4 \times 10^{8}$ cells $\mathrm{ml}^{-1}$. The rate of hydrolysis was determined from the increase in radioactivity in the LMW (TCA-soluble) fraction over time. TCA (final conc. $5 \%$ ) and BSA carrier (final conc $1 \mathrm{mg} \mathrm{ml}^{-1}$ ) were added to the samples. After incubation (20 to $40 \mathrm{~min}$ ), precipitated proteins were centrifuged ( $14000 \times g$ for $15 \mathrm{~min}$ ), and radioactivity in the supernatant ( 70 to $180 \mu l$ ) was assayed by liquid scintillation counting. Polyethylene centrifuge tubes ( $1.8 \mathrm{ml}$ capacity) were used for all the experiments except when glass scintillation vials $(20 \mathrm{ml}$ capacity) were used for time-course experiments. Con- 
trol samples with filtered artificial seawater without bacteria were also processed to examine abiotic degradation of ${ }^{3} \mathrm{H}$-BSA. Previous studies have shown that bacteria hydrolyze methyl- ${ }^{3} \mathrm{H}$-protein but do not assimilate the methylated residues (Keil \& Kirchman 1992). Therefore, the accumulation rate of ${ }^{3} \mathrm{H}$ in the LMW fraction represents the hydrolysis rate of ${ }^{3} \mathrm{H}$ BSA.

Hydrolysis of BSA by a natural assemblage of marine bacteria. To examine degradation of protein by natural bacterial assemblages, surface water was collected at Roosevelt Inlet on 12 October 1994. The sample water was filtered through $0.8 \mu \mathrm{m}$ Nuclepore filters by gravity to eliminate phytoplankton and grazers. The filtrate $(10 \mathrm{ml})$ was then incubated in glass vials $(20 \mathrm{ml}$ capacity) with an addition of either ${ }^{3} \mathrm{H}$-BSA or adsorbed ${ }^{3} \mathrm{H}$-BSA $(0.12$ or $0.8 \mu \mathrm{m}$ beads) at a final concentration of $38 \mathrm{ng}$ BSA ml-1. Subsamples were withdrawn over the time to determine hydrolysis of BSA from the accumulation of ${ }^{3} \mathrm{H}$ in TCA-soluble fraction. Controls consisted of autoclaved seawater with additions of ${ }^{3} \mathrm{H}$-BSA or adsorbed ${ }^{3} \mathrm{H}$-BSA.

Desorption of adsorbed ${ }^{3} \mathbf{H}$-BSA. To examine desorption of ${ }^{3} \mathrm{H}$-BSA adsorbed to 0.8 and $1.5 \mu \mathrm{m}$ beads, we added the suspension of beads $(5 \mu$ l, concentrations $1.6 \times 10^{9}$ and $4.8 \times 10^{8}$ particles $\mathrm{ml}^{-1}$ for 0.8 and $1.5 \mu \mathrm{m}$ beads, respectively) to artificial seawater $(700 \mu l)$. After the incubation $(10 \mathrm{~min})$, particles were sedimented by centrifugation $(14000 \times g$ for $10 \mathrm{~min})$. The $\%$ desorption was calculated from the radioactivity in the supernatant and the total radioactivity added.

Effects of beads on bacterial activity. We examined whether polystyrene latex beads affect bacterial uptake of organic matter. ${ }^{14} \mathrm{C}$-glucose (final conc. $310 \mathrm{nM})$ or ${ }^{14} \mathrm{C}$-leucine $(300 \mathrm{nM})$ were added to cell suspensions of mixed bacterial assemblage with or without the addition of $0.126 \mu \mathrm{m}$ diameter beads with adsorbed ${ }^{3} \mathrm{H}-\mathrm{BSA}$ (final particle abundance $4 \times 10^{9}$ beads $\mathrm{ml}^{-1}$ ). After the incubation (4 to $23 \mathrm{~min}$ ), cells were collected on $0.2 \mu \mathrm{m}$ membrane filters (Sartorius. cellulose nitrate) and radioassayed by liquid scintillation counting using a ${ }^{14} \mathrm{C} / 3 \mathrm{H}$ dual mode.

\section{RESULTS}

\section{Hydrolysis of ${ }^{3} \mathrm{H}$-BSA by mixed bacterial assemblages}

Hydrolysis of free and adsorbed ${ }^{3} \mathrm{H}$-BSA by mixed bacterial assemblages cultured on BSA media was examined by measuring the accumulation of LMW- ${ }^{3} \mathrm{H}$ during the incubation. The time course experiment revealed that bacteria hydrolyzed freely dissolved ${ }^{3} \mathrm{H}$ BSA much more rapidly than the adsorbed ${ }^{3} \mathrm{H}-\mathrm{BSA}$

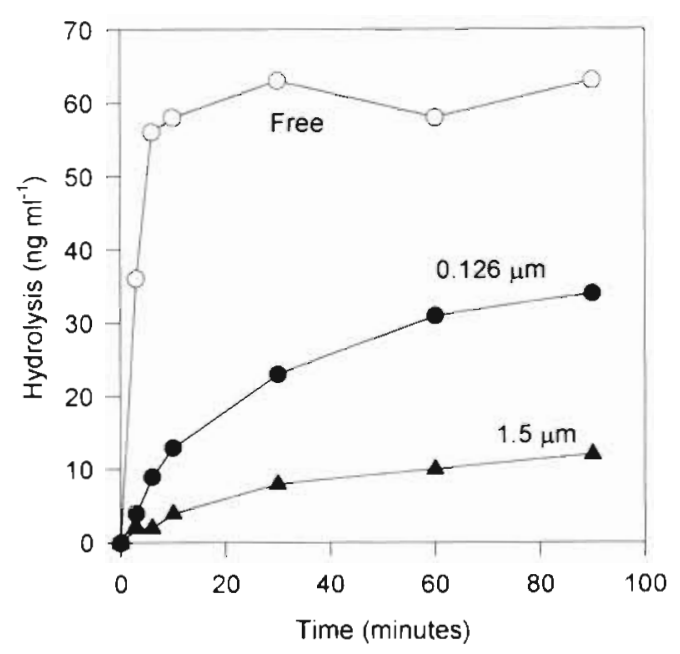

Fig. 1 Time course of the hydrolysis of ${ }^{3} \mathrm{H}$-BSA freely dissolved and adsorbed to beads (diameters 0.126 and $1.5 \mu \mathrm{m}$ ) by mixed assemblages of marine bacteria

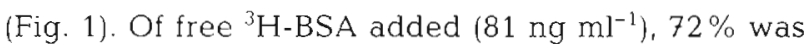
recovered as $\mathrm{LMW}-{ }^{3} \mathrm{H}$ after $1 \mathrm{~h}$ incubation (Fig. 1). Unrecovered ${ }^{3} \mathrm{H}(28 \%)$ probably reflects the loss of ${ }^{3} \mathrm{H}$ $\mathrm{BSA}$ due to adsorption to the walls of the incubation vials (Hollibaugh \& Azam 1983). The accumulation of LMW- ${ }^{3} \mathrm{H}$ was linear during the initial $10 \mathrm{~min}$ but the accumulation rate decreased substantially over longer incubation. We did not detect any increase of LWM- ${ }^{3} \mathrm{H}$ in filtered seawater controls with either free or adsorbed ${ }^{3} \mathrm{H}$-BSA during the initial 30 min (data not shown), indicating that abiotic degradation of ${ }^{3} \mathrm{H}-\mathrm{BSA}$ was negligible.

To compare degradation rates of free and adsorbed protein, we calculated the hydrolysis rates for the initial period of the incubation (4 min for free ${ }^{3} \mathrm{H}$-BSA, and $20 \mathrm{~min}$ for ${ }^{3} \mathrm{H}$-BSA adsorbed to beads). When $250 \mathrm{ng} \mathrm{ml}^{-1}$ of ${ }^{3} \mathrm{H}$-BSA was added, mixed assemblages of bacteria hydrolyzed free BSA at a rate of $130( \pm 12) \times$ $10^{-18} \mathrm{~g} \mathrm{BSA}_{\text {cell }}{ }^{-1} \mathrm{~h}^{-1}$ This rate was 25 to 250 times greater than the corresponding rates for nearly the same concentration (290 $\mathrm{ng} \mathrm{ml}^{-1}$ ) of BSA adsorbed to beads. Notably, the hydrolysis rates varied greatly depending on the diameter of the beads (Table 1). The hydrolysis rate was highest for the smallest beads $(0.126 \mu \mathrm{m}$ diameter) and lowest for the $0.86 \mu \mathrm{m}$ beads

To examine further the relation between hydrolysis of adsorbed protein and the size of colloids, we conducted experiments at different concentrations of ${ }^{3} \mathrm{H}$ BSA and numbers of beads (Table 2, Fig. 2). The \% hydrolysis decreased with increasing bead diameter in the range of 0.126 and $0.8 \mu \mathrm{m}$, and then increased with increasing diameter up to $1.5 \mu \mathrm{m}$ (Fig. 2). Although our data include the results from experiments with different batches of mixed bacterial assemblages (Table 2), 
Table 1 . Hydrolysis of ${ }^{3} \mathrm{H}$-BSA freely dissolved and adsorbed to polystyrene beads by mixed bacteria and 2 bacterial 1solates, PD2 and PD42. ${ }^{3} \mathrm{H}-\mathrm{BSA}$ concentration was $250 \mathrm{ng} \mathrm{ml}^{-1}$ for free and $290 \mathrm{ng} \mathrm{ml}^{-1}$ for adsorbed

\begin{tabular}{|c|c|c|c|c|}
\hline $\begin{array}{l}\text { Bacteria } \\
\text { type }\end{array}$ & $\begin{array}{l}\text { BSA type } \\
\text { (diam. of beads) }\end{array}$ & $\begin{array}{l}\text { Conc. of beads } \\
\text { (no } \mathrm{ml}^{-1} \text { ) }\end{array}$ & $\begin{array}{c}\text { Hydrolysis } \\
\left(10^{-18} \mathrm{~g} \mathrm{cell}^{-1} \mathrm{~min}^{-1}\right)\end{array}$ & $\%$ free ${ }^{d}$ \\
\hline \multirow[t]{4}{*}{ Mixed } & Free & & $130 \pm 12$ & 100 \\
\hline & $\begin{array}{l}\text { Adsorbed } \\
(0.126 \mu \mathrm{m})\end{array}$ & $3.8 \times 10^{9}$ & $6.4 \pm 0.1$ & 4.8 \\
\hline & $\begin{array}{l}\text { Adsorbed } \\
(0.840 \mu \mathrm{m})\end{array}$ & $7.6 \times 10^{7}$ & $0.8 \pm 0.2$ & 0.6 \\
\hline & $\begin{array}{l}\text { Adsorbed } \\
(1.500 \mu \mathrm{m})\end{array}$ & $2.3 \times 10^{7}$ & $2.1 \pm 0.2$ & 1.6 \\
\hline \multirow[t]{4}{*}{$\mathrm{PD} 2$} & Free & & $47 \pm 2.5$ & 100 \\
\hline & $\begin{array}{l}\text { Adsorbed } \\
(0.126 \mu \mathrm{m})\end{array}$ & $3.8 \times 10^{9}$ & $<0.2$ & $<0.4$ \\
\hline & $\begin{array}{l}\text { Adsorbed } \\
(0.840 \mu \mathrm{m})\end{array}$ & $7.6 \times 10^{7}$ & $<0.2$ & $<0.4$ \\
\hline & $\begin{array}{l}\text { Adsorbed } \\
(1.500 \mu \mathrm{m})\end{array}$ & $2.3 \times 10^{7}$ & $<0.2$ & $<0.4$ \\
\hline \multirow[t]{4}{*}{ PD42 } & Free & & $42 \pm 0.6$ & 100 \\
\hline & $\begin{array}{l}\text { Adsorbed } \\
(0.126 \mu \mathrm{m})\end{array}$ & $3.8 \times 10^{9}$ & $4.2 \pm 0.2$ & 10.2 \\
\hline & $\begin{array}{l}\text { Adsorbed } \\
(0.840 \mu \mathrm{m})\end{array}$ & $7.6 \times 10^{7}$ & $0.5 \pm 0.0$ & 1.1 \\
\hline & $\begin{array}{l}\text { Adsorbed } \\
(1.500 \mu \mathrm{m})\end{array}$ & $2.3 \times 10^{7}$ & $1.2 \pm 0.5$ & 2.8 \\
\hline
\end{tabular}

\section{Hydrolysis of BSA by natural bacterial assemblages}

To examine the degradation of protein by natural marine bacterial assemblages, we added ${ }^{3} \mathrm{H}$-BSA freely dissolved or adsorbed to beads $(0.126$ and $0.8 \mu \mathrm{m}$ diameter) at final concentrations of $38 \mathrm{ng}$ $\mathrm{ml}^{-1}$ to coastal seawater prefiltered through $0.8 \mathrm{\mu m}$ pore-size filters. Our results clearly indicated that the hydrolysis rate of free ${ }^{3} \mathrm{H}$-BSA was much greater than ${ }^{3} \mathrm{H}$-BSA adsorbed to beads (Fig. 3). The \% hydrolysis for free ${ }^{3} \mathrm{H}$-BSA during the initial. $26 \mathrm{~h}\left(1.1 \pm 0.07 \% \mathrm{~h}^{-1}\right)$ was 18 fold greater than the corresponding rate for ${ }^{3} \mathrm{H}$-BSA adsorbed to $0.126 \mu \mathrm{m}$ beads $\left(0.062 \pm 0.014 \% \mathrm{~h}^{-1}\right.$, initial $\left.20 \mathrm{~h}\right)$. The hydrolysis rate for free ${ }^{3} \mathrm{H}$-BSA decreased, while that for adsorbed ${ }^{3} \mathrm{H}$-BSA (0.126 $\mu \mathrm{m}$ beads) increased over longer incubation (Fig. 3), but even during the later period, the hydrolysis rate for adsorbed ${ }^{3} \mathrm{H}-\mathrm{BSA}\left(0.23 \pm 0.03 \% \mathrm{~h}^{-1} ; 20\right.$ to $44 \mathrm{~h})$ was only one-third of the rate for free ${ }^{3} \mathrm{H}$-BSA $\left(0.68 \pm 0.04 \% \mathrm{~h}^{-1} ; 26\right.$ to $\left.46 \mathrm{~h}\right)$. Hydrolysis of ${ }^{3} \mathrm{H}$-BSA adsorbed to $0.8 \mathrm{\mu m}$ beads was undetectable during the initial $20 \mathrm{~h}$. Although some accumulation of LMW $-{ }^{3} \mathrm{H}$ was detected afterwards, it was the general trend between \% hydrolysis (normalized to bacterial cell number) and the bead diameter was the same among the experiments (Fig. 2).

\section{Hydrolysis of ${ }^{3} \mathrm{H}-\mathrm{BSA}$ by bacterial isolates}

We found that hydrolysis rates of free ${ }^{3} \mathrm{H}$-BSA by 2 bacterial strains, PD2 and PD42, were about the same: $46.7( \pm 2.5) \times 10^{-18} \mathrm{~g} \mathrm{BSA} \mathrm{cell} \mathrm{l}^{-1} \mathrm{~h}^{-1}$ for PD2 and 41.6 $( \pm 2.5) \times 10^{-18} \mathrm{~g} \mathrm{BSA}$ cell ${ }^{-1} \mathrm{~h}^{-1}$ for PD42 (Table 1). But the hydrolysis of adsorbed ${ }^{3} \mathrm{H}$-BSA differed greatly. Hydrolysis by PD42 of adsorbed ${ }^{3} \mathrm{H}$-BSA was low but measurable (1 to $10 \%$ of free BSA, depending on the bead size), whereas the hydrolysis of ${ }^{3} \mathrm{H}$-BSA adsorbed to beads was not detectable for PD2 (Table 1). Kinetic analysis of the hydrolysis of free ${ }^{3} \mathrm{H}$-BSA revealed that half-saturation constants $\left(K_{\mathrm{m}}\right)$ and maximum rates of hydrolysis $\left(V_{\text {max }}\right)$ were $280 \mathrm{ng} \mathrm{ml}^{-1}$ and $1.5 \times 10^{-7} \mathrm{ng}$ cell $^{-1} \mathrm{~min}^{-1}$ for PD2 and $57 \mathrm{ng} \mathrm{m} \mathrm{m}^{-1}$ and $8.7 \times 10^{-8} \mathrm{ng}$ $\mathrm{cell}^{-1} \mathrm{~min}^{-1}$ for PD42, respectively, suggesting that proteases of these 2 strains differed. The $V_{\max } / K_{\mathrm{m}}$ value, an index of the affinity of enzyme to substrate, was 5.4 $\times 10^{-10}$ and $15.3 \times 10^{-10} \mathrm{ml} \mathrm{cell}{ }^{-1} \mathrm{~min}^{-1}$ for PD2 and PD42, respectively. close to the detection limit of our assay (ca $0.5 \%$ of total ${ }^{3} \mathrm{H}-\mathrm{BSA}$ added).

Total ${ }^{3} \mathrm{H}$ in seawater $\left({ }^{3} \mathrm{H}\right.$-BSA plus hydrolyzate) decreased over the incubation, suggesting that free

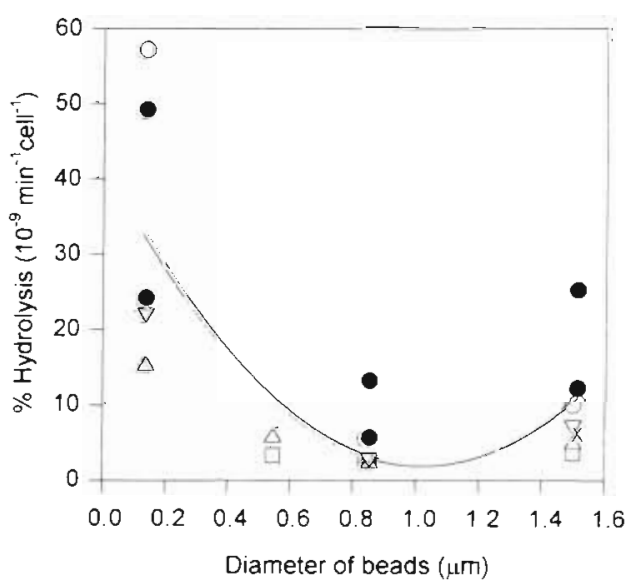

Fig. 2. \% hydrolysis of ${ }^{3} \mathrm{H}-\mathrm{BSA}$ adsorbed to polystyrene beads as a function of the diameter of beads. Different symbols represent different experiments: (0) Expt 1; (a) Expt 2; $(\Delta)$ Expt 3; $(\bullet)$ Expt $4 ;(\nabla)$ Expt 5 (see Table 2). The line is from a second order regression 
${ }^{3} \mathrm{H}$-BSA adsorbed to the walls of the incubation vials (Fig. 3). In contrast to free ${ }^{3} \mathrm{H}$ BSA, total ${ }^{3} \mathrm{H}$ added in seawater as adsorbed ${ }^{3} \mathrm{H}$-BSA was mostly recovered in the aqueous phase throughout the incubation, suggesting that adsorption of beads to the wall of incubation vials was insignificant.

\section{Desorption of ${ }^{3} \mathrm{H}$-BSA and effects of beads on bacterial metabolism}

Desorption of adsorbed BSA from polystyrene beads was $2.9 \%(0.8 \mu \mathrm{m}$ beads) and $3.0 \%$ (1.5 $\mu \mathrm{m}$ beads) of adsorbed protein. This percentage is small compared to $\%$ hydrolysis of adsorbed BSA in our experiments with $0.126 \mu \mathrm{m}$ beads, which usually exceeded $15 \%$ of total BSA added. This indicates that hydrolysis of desorbed ${ }^{3} \mathrm{H}$-BSA contributed little to the observed hydrolysis of ${ }^{3} \mathrm{H}-\mathrm{BSA}$ adsorbed to $0.126 \mu \mathrm{m}$ beads. On the other hand, the hydrolysis of ${ }^{3} \mathrm{H}$-BSA adsorbed to 0.8 and $1.5 \mu \mathrm{m}$ beads was 1 to $8 \%$ of total ${ }^{3} \mathrm{H}$-BSA added, suggesting that what appeared to have been hydrolysis of adsorbed ${ }^{3} \mathrm{H}$-BSA was in fact hydrolysis of desorbed ${ }^{3} \mathrm{H}$ BSA. Therefore, hydrolysis of ${ }^{3} \mathrm{H}-\mathrm{BSA}$ adsorbed to 0.8 and $1.5 \mu \mathrm{m}$ beads could have been overestimated to some extent. However, hydrolysis of this small amount of desorbed ${ }^{3} \mathrm{H}$-BSA does not affect our major observation that adsorbed BSA is degraded more slowly than dissolved BSA (Table 1, Fig. 3).

To examine if polystyrene beads affected bacterial activity, we added ${ }^{3} \mathrm{H}$-BSA adsorbed onto $0.126 \mu \mathrm{m}$ beads to bacterial suspensions and measured the uptake rate of ${ }^{14} \mathrm{C}$-glucose and ${ }^{14} \mathrm{C}$-leucine by mixed assemblages of bacteria. The addition of beads $\left(4 \times 10^{9}\right.$ particles $\mathrm{ml}^{-1}$ ) did not affect uptake rates of glucose and leucine by mixed bacterial assemblages (data not shown), suggesting that the low hydrolysis of adsorbed protein was not because the beads directly inhibited bacterial metabolism.

\section{DISCUSSION}

Marine colloids and submicron particles provide large surface areas in seawater. We estimate that the total surface area of these particles in oceanic surface water is on the order of $10 \mathrm{~m}^{2} \mathrm{~m}^{-3}$. For this calculation, we assume that numbers of submicron particles (average diameter $0.5 \mu \mathrm{m}$; Koike et al. 1990) and small col- loids (average diameter $0.05 \mu \mathrm{m}$; Wells \& Goldberg 1991) are $5 \times 10^{6}$ and $10^{9}$ particles $\mathrm{ml}^{-1}$ respectively and that colloids are spheres. This large surface area could have substantial implications for biogeochemical cycling in marine environments. Our interest here was to examine how adsorption of protein to a colloidal surface affects the degradation rate of proteins in seawater.

Investigators have long been interested in the effect of solid surfaces on bacterial activity and nutrient cycling. It has often been assumed that accumulation of organic matter on surfaces due to adsorption would facilitate bacterial utilization of the organic matter, leading to higher metabolic activities of bacteria on the surface (reviewed by van Loosdrecht et al. 1990. Fletcher 1991). However, data from recent studies are conflicting; effects of surface on degradation of organic matter could be stimulative, neutral (no effect), or even inhibitory (van Loosdrecht et al. 1990, Fletcher 1991). The results appear to vary depending on several factors, including concentration of organic matter on the surface and the nature of the interactions between organic matter and surfaces (Samuelson \& Kirchman 1990, van Loosdrecht et al. 1990, Griffith \& Fletcher 1991, Taylor 1995). 

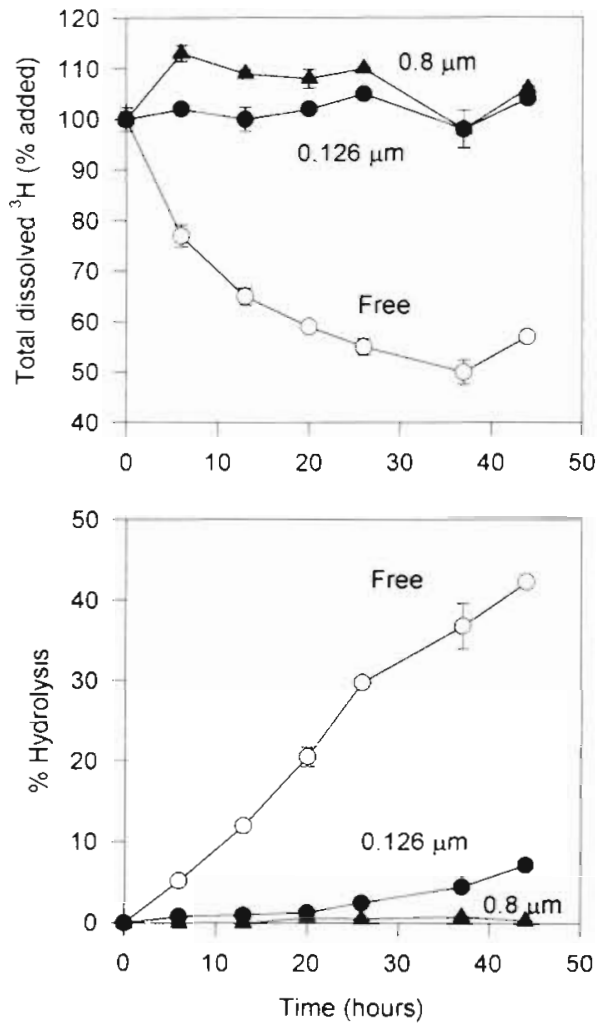

Fig. 3. Hydrolysis of ${ }^{3} \mathrm{H}-\mathrm{BS} A$ freely dissolved and adsorbed to beads (diameters 0.126 and $0.8 \mu \mathrm{m}$ ) by a natural bacterial assemblage from the Delaware Bay (USA). (A) Recovery of ${ }^{3} \mathrm{H}$ in the dissolved fraction. (B) Time course of the accumulation of LMW- ${ }^{3} \mathrm{H}$ as percentages of total ${ }^{3} \mathrm{H}$-BSA added. Error bars are ranges of duplicate experuments (vials)

Because surface-organic matter-bacteria interactions are apparently complex, we designed our experiments to focus on a model system with artificial polystyrene beads. Our results clearly indicated that the adsorption to model submicron particles greatly reduces the hydrolysis rate of protein by mixed assemblages of cultured bacteria (Fig. 1, Table 1), 2 isolates of marine bacteria (Table 1), and by a natural bacterial assemblage (Fig. 3). Hydrolysis rates of the protein adsorbed to $0.1-1.5 \mu \mathrm{m}$ beads could be more than 2 orders of magnitude lower than those of freely dissolved protein.

Transport of colloids to bacterial cell surfaces could be one factor affecting hydrolysis rates of free and adsorbed protein by bacteria. Note that only proteases associated with bacterial surfaces, not extracellular 'free' proteases, were responsible for the hydrolysis of ${ }^{3} \mathrm{H}-\mathrm{BSA}$ in our experiments with cultured bacteria, because bacteria had been washed and resuspended with artificial. seawater immediately before use. Johnson \& Kepkay (1992) suggested that the collision rate $(\mathrm{d} N / \mathrm{d} t)$ of colloids to bacteria in seawater can be pre- dicted by the following formula:

$$
\mathrm{d} N / \mathrm{d} t=E \beta\left(r_{1}, r_{2}\right) N_{1} N_{2}
$$

where $E$ is the collision efficiency factor, $\beta$ is a collision function for bacteria and colloids with diameters $r_{1}$ and $r_{2}$, and $N_{1}, N_{2}$ are concentrations of bacteria and colloids. The collision function $(\beta)$ accounts for Brownian motion $\left(\beta_{B}\right)$ :

$$
\beta_{B}\left(I_{1}, I_{2}\right)=\frac{2 k T\left(r_{1}+r_{2}\right)^{2}}{3 \mu\left(r_{1} r_{2}\right)}
$$

and bacterial swimming $\left(\beta_{M}\right)$ :

$$
\beta_{\mathrm{M}}\left(r_{1}, r_{2}\right)=\Delta U \pi\left(r_{1}+r_{2}\right)^{2}
$$

where $k$ is Boltzmann's constant, $\mu$ is absolute viscosity, $T$ is absolute temperature and $\Delta U$ is the difference in velocity of particle and bacterium.

Johnson \& Kepkay's (1992) model predicts that the collision rate constant for frec BSA molecules (particles with a diameter of $0.01 \mu \mathrm{m}$ ) is 10 -fold greater than that for $0.126 \mu$ m diameter beads (Table 3 ). This model prediction is consistent with our results with mixed assemblages and strain PD42, which indicated that the rate constant for hydrolysis dropped about 10 -fold when BSA was adsorbed to $0.126 \mu \mathrm{m}$ diameter beads (Table 3). The Brownian motion model also predicts that bacteria collide least frequently with particles of the same diameter, which is also consistent with our results showing that the hydrolysis rate was lowest for BSA adsorbed to $0.8 \mu \mathrm{m}$ beads (close to bacterial diameter of ca $1 \mu \mathrm{m}$ ). Hydrolysis of BSA adsorbed to $1.5 \mu \mathrm{m}$ beads was higher than that adsorbed to $0.8 \mu \mathrm{m}$ beads (Fig. 2, Table 3), perhaps because of collisions caused by bacterial swimming, which can enhance collisions between colloids and bacteria depending on the swimming speed (Johnson \& Kepkay 1992; Table 3).

We note that rate constants are lower for hydrolysis than for collision (Table 3), probably because bacteria hydrolyze only a part of the BSA molecules adsorbed on a bead per collision. It is unclear what proportion of BSA can be hydrolyzed per collision, and whether or not the size of particles affects this proportion. Despite this limitation, the above comparisons between the collision model and our experimental results suggest that hydrolysis rates of free and adsorbed BSA were influenced primarily by the transport rate of BSA to bacteria.

Other data, however, indicate that physics (transport) does not explain all of our results. We found that the hydrolysis of free and adsorbed BSA by 2 bacterial strains (PD2 and PD42) differed greatly (Table 1); both bacterial strains hydrolyzed free BSA at similar rates. but the hydrolysis of adsorbed BSA was much more pronounced for PD42 than for PD2. This difference cannot be explained by some difference in Brownian 
teases (or protein-binding proteins) and adsorbed protein should hold even for hydrophilic submicron particles. Finally, physical relations between particle size and collision frequency should apply, in principle, to any kind of colloidal particle, regardless of the chemical compositions of the particles (Johnson \& Kepkay 1992). The model system that we devised in this study may be a useful tool to further investigate relations between surface characteristics of colloids and bacterial degradation of adsorbed organic matter in seawater.

Acknowledgements. We thank I. Koike, K. Kogure, and N. H. Borch for suggestions. R. Benner, R. Keil and B. Logan provided helpful comments on the manuscript. This study was supported by grants from the Ministry of Education. Science, and Culture of Japan and NSF. Travel expenses for T.N. were partly supported by the Yoshida Foundation of Science and Technology.

\section{LITERATURE CITED}

Benner R, Pakulski JD, McCarthy M, Hedges JT, Hatcher PG (1992) Bulk chemical characteristics of dissolved organic matter in the ocean. Science 255:1561-1564

Carlson CA, Ducklow HW, Michaels AF (1994) Annual flux of dissolved organic carbon from the euphotic zone in the northwestern Sargasso Sea. Nature 371:405-408

Fletcher M (1991) The physiological activity of bacteria attached to solid surfaces. Adv microb Physiol 32:53-85

Griffith PC, Fletcher M (1991) Hydrolysis of protein and model dipeptide substrates by attached and nonattached marine $P_{\text {seudomonas }} \mathrm{sp}$. strain MCIMB 2021. Appl environ Microbiol 57:2186-2191

Hedges JI (1988) Polymerization of humic substances in natural environments. In: Frimmel FH, Christman RF (eds) Humic substances and their role in the environment. John Wiley \& Sons Ltd, Chichester, p 45-58

Hobbie JE, Daley RJ, Jasper S (1977) Use of Nuclepore filters for counting bacteria by fluorescence microscopy. Appl environ Microbiol 33:1225-1228

Hollibaugh JT, Azam F (1983) Microbial degradation of dissolved proteins in seawater. Limnol Oceanogr 28 : $1104-1116$

Johnson BD, Kepkay PE (1992) Colloid transport and bacterial utilization of oceanic DOC. Deep Sea Res 39:855-869

This article was presented by S. Y. Newell (Senior Editonal Advisorl, Sapelo Island, Georgia, USA
Keil RG, Kirchman DL (1992) Bacterial utilization of protein and methylated protein and its implications for studies of protein degradation in aquatic ecosystems. Appl environ Microbiol 58.1374-1375

Keil RG, Kirchman DL (1993) Dissolved combined amino acids: chemical form and utilization by marine bacteria. Limnol Oceanogr 38:1256-1270

Keil RG, Kirchman DL (1994) Abiotic transformation of labile protein to refractory protein in seawater. Mar Chem 45 : $187-196$

Kirchman DL, Henry DL, Dexter SC (1989) Adsorption of proteins to surfaces in seawater. Mar Chem 27:201-217

Koike I, Hara S, Terauchi K, Kogure K (1990) The role of submicrometer particles in the ocean. Nature 345:242-244

Lee C, Wakeham SG (1992) Organic matter in the water column: future research challenges. Mar Chem 39:95-118

Nagata T, Koike I (1995) Marine colloids: their roles in food webs and biogeochemical fluxes. In: Sakai $H$, Nozaki $Y$ (eds) Biogeochemical processes and ocean flux in the Western Pacific. Terra Scientific Publishing Co, Tokyo, p 275-292

Peltzer ET, Hayward NA (in press) Spatial and temporal variability of total organic carbon along $140^{\circ} \mathrm{W}$ in the equatorial Pacific Ocean in 1992. Deep Sea Res

Samuelson MO, Kirchman DL (1990) Degradation of adsorbed protein by attached bacteria in relationship to surface hydrophobicity. Appl environ Microbiol 56: 3643-3648

Soderquist ME, Walton AG (1980) Structural changes in proteins adsorbed on polymer surfaces. J Colloid Interface Sci $75: 386-397$

Taylor GT (1995) Microbial degradation of sorbed and dissolved protein in seawater. Limnol Oceanogr 40:875-885

Taylor GT, Troy PJ, Nullet M, Sharma SK, Liebert BE (1994) Protein adsorption from seawater onto solid substrata: II. Behavior of bound protein and its influence on interfacial properties. Mar Chem 47:21-39

van Loosdrecht MCM, Lyklema J, Norde W, Zehnder AJB (1990) Influence of interfaces on microbial activity. Microbiol Rev 54:75-87

Wells ML, Goldberg ED (1991) Occurrence of small colloids in sea water. Nature 353:342-344

Wells ML, Goldberg ED (1994) The distribution of colloids in the North Atlantic and Southern Ocean. Limnol Oceanogr $39: 286-302$

Yamamoto S, Ishiwatari R (1989) A study of the formation mechanisms of sedimentary humic substances. II. Proteinbased melanoidin model. Org Geochem 14:479-489

Manuscript first received: March 1, 1995

Revised version accepted: August 15, 1995 